\title{
The presence of ANP in rat peritoneal mast cells
}

\author{
Marina G MARTYNOVA ${ }^{1, *}$, Olga A BYSTROVA ${ }^{1}$, Olga M MOISEEVA ${ }^{2}$, Anton L EVDONIN ${ }^{1}$, Kirill A \\ KONDRATOV $^{1}$, Natalja D MEDVEDEVA ${ }^{1}$
}

${ }^{1}$ Institute of Cytology, Russian Academy of Sciences, St. Petersburg 196064, Russia

${ }^{2}$ Almazovs' Research Institute of Cardiology, St. Petersburg 194056, Russia

\begin{abstract}
Atrial natriuretic peptide (ANP) is an important component of the natriuretic peptide system. A great role in many regulatory systems is played by mast cells. Meanwhile involvement of these cells in ANP activity is poorly studied. In this work, we have shown the presence of ANP in rat peritoneal mast cells. Pure fraction of mast cells was obtained by separation of rat peritoneal cells on a Percoll density gradient. By Western blotting, two ANP-immunoreactive proteins of molecular masses of $2.5 \mathrm{kDa}$ and $16.9 \mathrm{kDa}$ were detected in lysates from these mast cells. Electron microscope immunogold labeling has revealed the presence of ANP-immunoreactive material in storage, secreting and released granules of mast cells. Our findings indicate the rat peritoneal mast cells to contain both ANP prohormone and ANP. These both peptides are located in mast cell secretory granules and released by mechanism of degranulation. It is discussed that many mast cell functions might be due to production of natriuretic peptides by these cells.
\end{abstract}

Keywords: natriuretic peptide system, secretory granules, ANP-immunoreactivity, proANP.

\section{INTRODUCTION}

Atrial natriuretic peptide (ANP) is a hormone with diuretic, natriuretic, and vasodilating properties. This peptide is mainly produced by atrial cardiomyocytes [1]. The ANP secretion by cardiomyocytes is indicated by the presence of specific secretory vesicles, the so-called atrial granules in these cells. The content of the atrial granules is released under effect of overload, oxygen deficiency, and many other physiological and pathological processes in myocardium. ANP is also produced by ovine fibroblasts infiltrating the myocardial infarct [2], by cells of rat [3] and bovine [4] heart conductive system, neurons of the rat brain [5], cells of the rat thymus [6], cells of the bovine cornea [7], rat vascular smooth muscle cells [8], and murine macrophages [9].

In the heart, apart from cardiomyocytes, the ANP-immunoreactive material was also found in mast cells [10]. It is not known whether ANP is also located in mast cells of some other places apart from myocardium. As a model, we have chosen mast cells of rat peritoneal cavity. They are characterized by the presence in a suspension, which

\footnotetext{
*Correspondence: Marina G MARTYNOVA

E-mail: heartdev@mail.cytspb.rssi.ru
}

allows obtaining their pure population for biochemical analysis by a gradient density fractionation. Mast cells are multifunctional cells that under effect of immune, nervous, humoral, or physicochemical stimuli are able to selectively release biogenic amines, acid glucoseamineglycans, neutral proteases, growth factors, a number of cytokines, arachidonic acid metabolites, and other bioactive substances (for review, see [11]). Secretion of mediators from mast cells may occur by the regular exocytosis of secretory granules, i.e. degranulation, or by differential release without degranulation [12]. During degranulation, storage granules are transformed into secreting granules; the initial ultrastructural sign of this transformation is the granule matrix disorganization [13]. A high sensitivity to a broad spectrum of stimuli and the remarkable variety of generated and secreted mediators allow mast cells, alongside with the nervous, endocrine, and immune system cells, to act as an important regulator at the tissue and organism levels. This work has shown mast cells of the rat peritoneal cavity to be ANP-producing cells and, hence participants of the natriuretic peptide system.

\section{MATERIALS AND METHODS}

Isolation of mast cells

Pure fraction of mast cells was isolated from suspension of rat 
peritoneal cells by cell separation on a Percoll density gradient as described in the detailed protocol [14]. Six adult Wistar rats weighing 250-300 g were used. After ether anesthesia and decapitation, $10 \mathrm{ml}$ PBS were injected into the animal peritoneal cavity; on a gentle massage of abdomen, the peritoneal cavity was opened and a cell washout was collected with a Pasteur pipette. The washout pooled from 6 rats were centrifuged at $120 \times \mathrm{g}$ for $10 \mathrm{~min}$, the pellet resuspended in $0.5 \mathrm{ml}$ PBS, and the resulted cell suspension layered on the $88 \%$ Percoll gradient. The Percoll gradient was obtained by addition of $0.7 \mathrm{ml}$ of 10 -fold concentrated RPMI (Gibco BRL) to 200 $\mathrm{mM}$ Hepes/1 M NaOH, $\mathrm{pH} 7.0$, and centrifugation at $17,000 \times \mathrm{g}$ for $20 \mathrm{~min}$. The preformed Percoll gradient with cell suspension layered on the top was centrifuged at $450 \times \mathrm{g}$ for $15 \mathrm{~min}$. Fraction of mast cells that now occupied the lower part of the tube was collected and washed twice in PBS. Samples of cell suspension for electron microscopy were taken before (sample 1) and after (sample 2) separation in Percoll. Isolated cells were studied by Western blot analysis and electron microscope immunocytochemistry.

\section{Western blot analysis}

Purified mast cells were lysed in the buffer solution of the following composition $(\mathrm{mM})$ : $10 \times$ Tris- $\mathrm{HCl}, \mathrm{pH} 7.4,150 \mathrm{NaCl}, 0.5 \%$ Nonidet-P40, 0.2 aprotinin, 0.2 leupeptin, 1 Na-orthovanadate, 1 Na-fluoride, 0.2 phenyl methylsulfonyl fluoride, and $20 \%$ glycerol. Proteins of the lysates were separated by $20 \%$ SDS polyacrylamide gel electrophoresis [15] and transferred on a nitrocellulose membrane [16]. Detection of ANP-immunoreactive proteins was performed with primary polyclonal rabbit antibody to the rat synthetic C-terminal ANP (amino acids 99-126, Peninsula Lab. Inc., Bachem) diluted 1:1000, and horseradish peroxidase-conjugated goat secondary antibody to mouse IgG (Sigma). Proteins on immunoblots were revealed by the method of enhanced chemiluminescence. The commercial rat ANP (Sigma) served as control. Kit for molecular weights from 2.5 to $17 \mathrm{kDa}$ (Sigma) was used for calibration.

\section{Electron Microscope Immunocytochemistry}

The following antibodies were used: the same primary antibody as for Western blotting, diluted 1:1000, and gold-conjugated $(10 \mathrm{~nm})$ Protein A (Sigma) diluted 1:20 as secondary antibody.

Cells were fixed with $2.5 \%$ glutaraldehyde in $0.1 \mathrm{M}$ sodium cacodylate buffer, $\mathrm{pH} 7.4$, for $1 \mathrm{~h}$, postfixed with $1 \% \mathrm{OsO}_{4}$, stained en bloc with uranyl acetate, dehydrated and embedded in Epon-Araldit according to the standard procedure. Ultrathin sections were cut with a diamante knife and mounted on nickel grids. The grids with sections were treated in $\mathrm{H}_{2} \mathrm{O}_{2}$ and then incubated overnight at $4{ }^{\circ} \mathrm{C}$ with primary antibody followed by incubation for $1 \mathrm{~h}$ at room temperature with the secondary antibody. The preparations were stained with uranyl acetate and lead citrate and examined under a JEM 7A electron microscope at $80 \mathrm{kV}$. Specificity of immunostaining was assessed with the following control: omission of the primary antiserum step and application of the secondary antibody alone. The control gave negative results, i.e., insignificant random deposits of gold particles on the sections. The share of mast cells in samples 1 and 2 was calculated by means of a light microscope on semithin sections stained with methylene blue. For each sample 300 cells were analyzed.

\section{RESULTS}

The whole cell suspension from rat peritoneal fluid (sample 1) contained about $5 \%$ of mast cells (Fig. 1). Apart from mast cells, lymphocytes, eosinophils, neutrophils, and monocytes were also present. After fractionation in Percoll (sample 2) the amount of mast cells in the suspension reached $98 \%$ (Fig. 2). In both samples, mast cells had similar ultrastructure, which indicates their good preservation during the isolation procedure. Mast cells had a roundish shape and measured 7-9 $\mu \mathrm{m}$ in diameter. The cell surface was covered with microvilli. The ovoid nucleus had a peripheral region of condensed chromatin. The cytoplasm was filled with numerous spherical membranebound granules, approximately 300-400 $\mathrm{nm}$ in diameter. Most mast cells were filled with morphologically uniform granules, the so-called storage granules, with a homogeneous electron-dense material. Same of mast cells were in

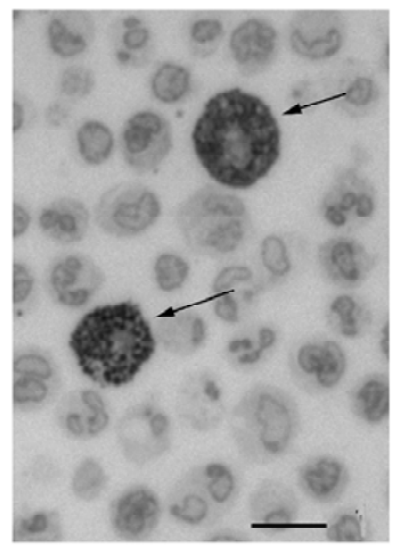

Fig. 1 Mast cells (arrows) among other cells inhabited the rat peritoneal cavity (sample 1, before fractionation in Percoll). Semithin section stained with methylene blue. Bar $=5 \mu \mathrm{m}$.

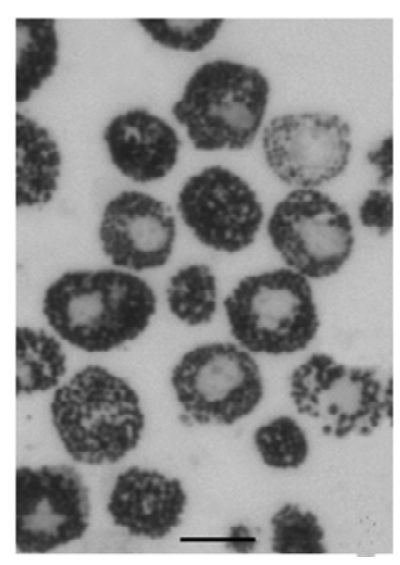

Fig. 2 Mast cells after isolation in Percoll (sample 2).Semithin section stained with methylene blue. Bar=5 $\mu \mathrm{m}$. 


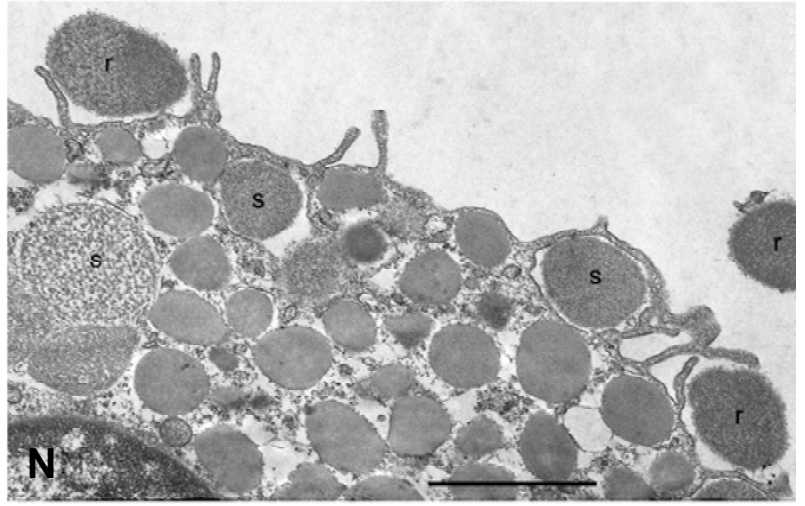

Fig. 3 Electron micrograph of a mast cell in the state of degranulation. In the cell, among storage granules with homogeneous material, the secreting granules (s) with disorganized matrix and the released granules (r) near the cell surface are seen. $\mathrm{N}$, nucleus. Bar $=1 \mu \mathrm{m}$.

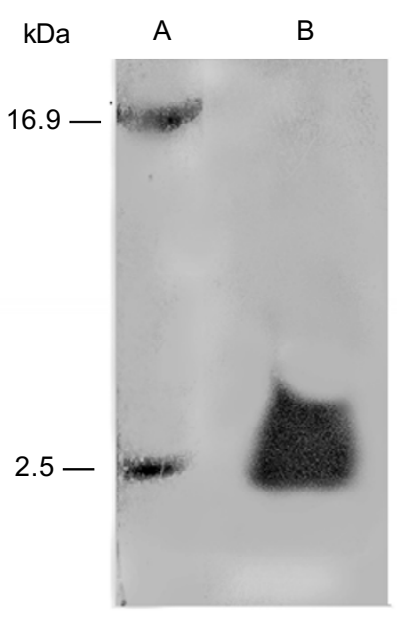

Fig. 4 Western blot of rat peritoneal mast cell lysate (line A) and synthetic rat ANP peptide (line B) reacted with antibodies against rat C-terminal ANP (99-126) after separation by SDS polyacrylamide gel electrophoresis. Two bands $-2.5 \mathrm{kDa}$ and $16.9 \mathrm{kDa}$ indicate the presence of the mature ANP and proANP respectively.

the state of spontaneous degranulation. These cells contained granules of two types: the storage granules and secreting granules with greatly reorganized matrices of decreased density (Fig. 3). Near these cells, granules devoid of perigranular membrane exposed to extracellular compartment could be seen (Fig. 3). Apart from the granules the mast cell cytoplasm contained a small amount of short canaliculi of rough endoplasmic reticulum and small mitochondria. Occasionally, centriole was observed near the nucleus.

\section{Western blot analysis}

Identification of ANP-immunoreactive proteins in peritoneal mast cell lysate (Fig. 4) shows the presence of two proteins recognized by antibody to $\mathrm{C}$-terminal portion of ANP. These proteins had molecular masses of approximately $2.5 \mathrm{kDa}$ and $16.9 \mathrm{kDa}$. The lower weight protein position corresponded to that of control rat ANP.

\section{Electron Microscope Immunocytochemistry}

Intracellular localization of ANP-immunoreactive material was demonstrated at the electron microscope level by immunogold labeling. Immunostaining was found to be restricted to the secretory granules of mast cells from both the 1st and the 2nd samples. Storage (Fig. 5) and secreting (Fig. 6) granules as well as granules lying free near mast cell surface (Fig. 7) were labeled. No immunogold particle localization over cytosol or any organelles of mast

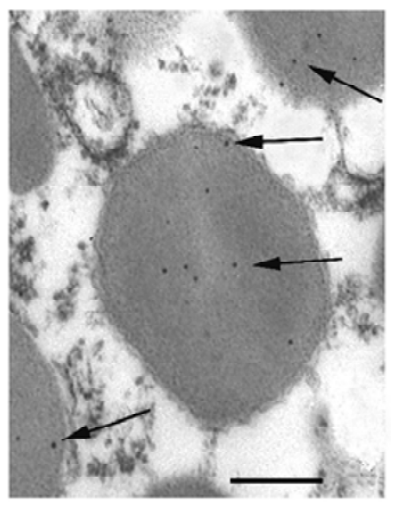

Fig. 5 Immunoelectron micrograph showing the presence of ANPimmunoreactive material in the storage granule of mast cell. Same of gold particles are marked by arrows. Bar $=0.2 \mu \mathrm{m}$.

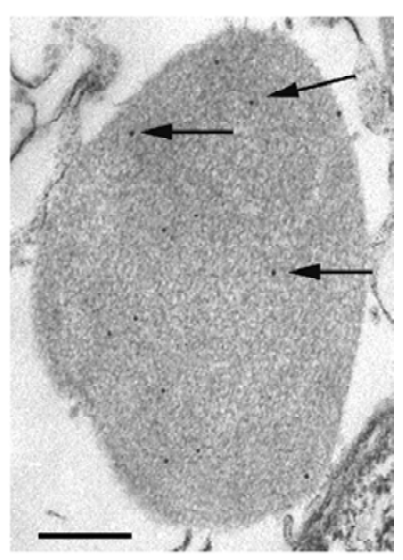

Fig. 6 ANP-positive immunostaining in the secreting granule of mast cell. Same of gold particles are marked by arrows. Bar $=0.2 \mu \mathrm{m}$. 
cells except the granules was revealed. In ultrathin sections of cells from the 1 st sample, granules of eosinophils also were weakly immunoreactive (Fig. 8). The central part of the eosinophil granules was occupied by crystalloid electron-dense structures. The label was located to the equal degree on all components of the granules. No reaction was observed in other cells. Control preparations (without treatment with primary antibody) showed negative result.

\section{DISCUSSION}

After fractionation in the Percoll gradient the cell suspension was composed by $98 \%$ of mast cells. The purity of this population is a guaranty that the ANP-immunoreactive material revealed by the Western blot method originates from mast cells. ANP is known to be formed from a

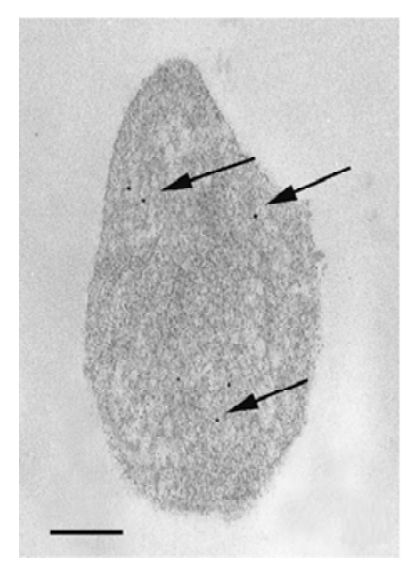

Fig. 7 ANP labeling in the released granule of mast cell. Same of gold particles are marked by arrows. Bar $=0.2 \mu \mathrm{m}$.

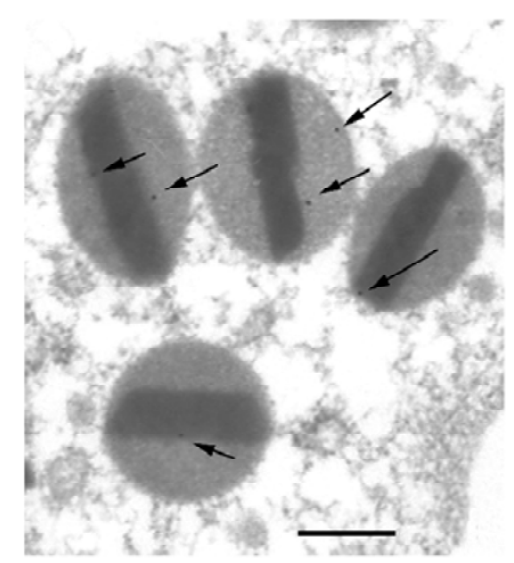

Fig. 8 The granules of eosinophil weakly immunostained for ANP. Arrows indicate gold particles deposited on the granules. $\mathrm{Bar}=0.5 \mu \mathrm{m}$. high-molecular precursor, proatrial natriuretic peptide (proANP) composed of 126 amino acid residues. The Cterminal fragment of this molecule represents the mature ANP form (99-126) resulted from cleavage of the prohormone (for review, see [17]). However, the uncleaved proANP also is released into blood and circulates together with the mature ANP [18]. The presence of proANP (1$126,16.9 \mathrm{kDa})$, but not of the mature ANP (99-126, 2.5 $\mathrm{kDa}$ ) was shown in the extracts of rat atrium tissues [3]. In the rat peritoneal mast cells, we have revealed the presence of two ANP-immunoreactive proteins. One of them had the same molecular mass as the mature ANP - 2.5 $\mathrm{kDa}$, whereas the second protein had molecular mass 16 . $9 \mathrm{kDa}$ that corresponds to the mass of the full length rat proANP. Thus, our data indicate the rat peritoneal mast cells to contain simultaneously both the mature ANP and its precursor.

The electron microscope immunocytochemistry has shown the ANP-immunoreactive material to be located in mast cell granules. The presence of labeled material in the storage, secreting and released granules indicates that secretion of ANP from mast cell occurs by the classical mechanism of degranulation.

The wide spread of mast cells in the body possibly accounts for detection of ANP in almost all vertebrate tissues [19]. Many biological functions of mast cells, such as immunoregulation potential [20], antitumar effect [21] and others can be due to their generating ANP.

An important peculiarity of mast cells is their ability to produce transmitters that have opposite effects on the same process. For instance, mast cells produce both histamine that has proinflammatory effect and heparin that has antiinflammatory effect. Recently, the rat heart mast cells and HMC-1 cells (the human mast cell line) have been shown to contain renin - an activator of the renin-angiotensinaldosterone system [22] and natural antagonist of ANP [23, $24]$. Contrary to the diuretic ANP, renin produces antidiuretic effect. An opinion is expressed that the cardiovascular homeostasis is maintained by a balance between the system of natriuretic peptide and the renin-angiotensinaldosterone system [25]. Thus, by secreting certain amounts of renin and/or ANP, mast cells can effectively regulate this balance.

Peritoneal mast cells play an important role in abdominal pathological processes. Thus, they perform protective function in pathogenesis of septic peritonitis [26]. Abdominal surgery has also been shown to produce mast cell degranulation and an increase of mast cell-derived factors in peritoneal fluid [27]. The presence of ANP revealed in peritoneal mast cells may, on the one hand, explain many known functions of these cells, and, on the other hand, anticipate some of their yet unexplored biological effects 
extending the functional range of mast cells. Rat peritoneal mast cells have been found to release histamine (proinflammatory factor) in response to the ANP action $[28,29]$. It may be suggested that during intraperitoneal inflammation this process occurs in an autocrine fashion due to release of ANP from activated mast cells. Interestingly, ANP also reduces secretion of inflammatory mediators in macrophages, and, therefore, has anti-inflammatory potential [30]. These data indicate again the functional dualism of mast cells. Owing to its biological effects, the mast cell-derived ANP may be of a great importance for regulation of the physiological state of abdominal organs. For example, ANP has been reported to affect ovarian functions in mice [31].

The presence of the ANP-immunoreactive material in eosinophil granules, which has been revealed in our work, might be due to production of this peptide by these eosinophils and/or to their absorption of ANP released by other cells, probably mast cells. The latter suggestion is confirmed by the data showing that eosinophils are able to take up the released products of mast cell granules [32].

\section{ACKNOWLEDGEMENTS}

We are very grateful to Dr. Leonid Z PEVZNER for correcting the English text. This work is partly supported by the Russian Foundation for Basic Research (grant 0504-49393).

Received, Jun 30, 2005

Revised, Sep 13, 2005

Accepted, Oct 12, 2005

\section{REFERENCES}

1 Reinecke M, Nehls M, Forssmann WG. Phylogenetic aspects of cardiac hormones as revealed by immunocytochemistry, electronmicroscopy, and bioessay. Peptides 1985; 6 (Suppl. 3): 321-31.

2 Cameron VA, Rademaker MT, Ellmers LJ, et al. Atrial (ANP) and brain natriuretic peptide (BNP) expression after myocardial infarction in sheep: ANP is synthesized by fibroblasts infiltrating the infarct. Endocrinology 2000; 141:4690-7.

3 Cantin M, Thibault G, Haile-Meskel H, et al. Atrial natriuretic factor in the impulse-conduction system of rat cardiac ventricles. Cell Tissue Res 1989; 256:309-25.

4 Hansson M, Forsgren S. Atrial natriuretic peptide in the innervation of the bovine heart conductive system: relationship with substance $\mathrm{P}$ and autonomic innervation - immunohistochemical studies. Neurosci Lett 1994; 179:123-6.

5 Jacobowitz DM, Skofitsch G, Keiser HR, Eskay RL, Zamir N. Evidence for the existence of atrial natriuretic factor containing neurons in the rat brain. Neuroendocrinology 1985; 40:92-4.

6 Vollmar AM, Wolf R, Schulz R. Co-expression of the natriuretic peptides (ANP, BNP, CNP) and their receptors in normal and acutely involuted rat thymus. J Neuroimmunol 1995; 57:117-27.
7 Kim SZ, Kim HS, Lee KS, et al. Coexistence of C-type natriuretic peptide and atrial natriuretic peptide system in the bovine cornea. Invest Ophthalmol Vis Sci 2000; 41:2671-7.

8 Woodard GE, Rosado JA, Brown J. Expression and control of Ctype natriuretic peptide in rat vascular smooth muscle cells. Am J Physiol Regul Integr Comp Physiol 2002; 282:R156-65.

9 Vollmar AV, Schulz R. Gene expression and secretion of atrial natriuretic peptide by murine macrophages. J Clin Invest 1994; 94:539-45.

10 Belloni AS, Guidolin D, Salmaso R, et al. Adrenomedullin, ANP and BNP are colocalized in a subset of endocrine cells in the rat heart. Int J Mol Med 2005; 15:567-71.

11 Metcalfe DD, Baram D, Mekori YA. Mast cell. Physiol Rev 1997; 77:1033-79.

12 Kraeuter Kops S, Theoharides TC, Cronin CT, Kashgarian MG, Askenase PW. Ultrastructural characteristics of rat peritoneal mast cells undergoing differential release of serotonin without histamine and without degranulation. Cell Tissue Res 1990; 262: 415-24.

13 Popov AA. Ultrastructural changes in the size of mast cell granules and in the granular matrix during an experimental anaphylactic shock. Anat Anz 1988; 166:267-73.

14 Németh A, Röhlich P. Rapid separation of rat peritoneal mast cells with Percoll. Eur J Cell Biol 1980; 20:272-5.

15 Laemmli UK. Cleavage of structural proteins during the assembly of the head of bacteriophage T4. Nature 1970; 227:680-5.

16 Towbin H, Staehelin T, Gordon J. Electrophoretic transfer of proteins from polyacrylamide gels to nitrocellulose sheets: procedure and some applications. Proc Nat Acad Sci U S A 1979; 76: 4350-4.

17 Takei Y. Does the natriuretic peptide system exist throughout the animal and plant kingdom? Comp Biochem Physiol B Biochem Mol Biol 2001; 129:559-73.

18 Itoh $\mathrm{H}$, Nakao K, Sugawara A, et al. Gamma-atrial natriuretic polypeptide (gamma-ANP)-derived peptide in human plasma: cosecretion of N-terminal gamma-ANP fragment and alpha-ANP. J Clin Endocrinol Metab 1988; 67:429-37.

19 Vesely DL, Palmer PA, Giordano AT. Atrial natriuretic factor prohormone peptides are present in a variety of tissues. Peptides 1992; 13:165-70.

20 Mohapatra SS, Lockey RF, Vesely DL, Gower WR Jr. Natriuretic peptides and genesis of asthma: an emerging paradigm. $\mathrm{J}$ Allergy Clin Immunol 2004; 114:520-6.

21 Vesely DL, Clark LC, Garces AN, et al. Novel therapeutic approach for cancer using four cardiovascular hormones. Eur J Clin Invest 2004; 34:674-82.

22 Silver RB, Reid AC, Mackins CJ, et al. Mast cell: a unique source of renin. Proc Nat Acad Sci U S A 2004; 101:13607-12.

23 Boomsma F, van den Meiracker AH. Atrial and B-type natriuretic peptides: from the research lab to clinical practice. Ned Tijdschr Geneeskd 2003; 147:743-8.

24 Cea LB. Natriuretic peptide family: new aspects. Curr Med Chem Cardiovasc Hematol Agents 2005; 3:87-98.

25 Kishimoto I, Saito Y, Li Y, Nakao K. Cross-talk between the natriuretic peptide system and the angiotensin system. Nippon Rinsho 2002; 60:1923-8.

26 Echenacher B, Mannel DN, Hultner L. Critical protective role of mast cells in a model of acute septic peritonitis. Nature 1996; 381:75-7. 
27 De Jonge WJ, The FO, van der Coelen D, et al. Mast cell degranulation during abdominal surgery initiates postoperative ileus in mice. Gastroenterology 2004; 127:535-45.

28 Yoshida H, Inagaki Y, Yamaki K, et al. Histamine release induced by human natriuretic peptide from rat peritoneal mast cells. Regul Pept 1996; 61:45-9.

29 Chai $\mathrm{OH}$, Lee $\mathrm{YH}$, Han EH, et al. Atrial natriuretic peptide induces rat peritoneal mast cell activation by cGMP-independent and calcium uptake-dependent mechanism. Exp Mol Med 2000; 32:179-86.
30 Kiemer AK, Vollmar AM. The atrial natriuretic peptide regulates the production of inflammatory mediators in macrophages. Ann Rheum Dis 2001; 60 (Suppl 3):iii68-70.

31 Tsai EM, Yang YY, Lee TT, et al. Atrial natriuretic peptide inhibits ovarian function in female mice. Eur J Obstet Gynecol Reprod Biol 2005; 119:215-8.

32 Baggiolini M, Horisberger U, Martin U. Phagocytosis of mast cell granules by mononuclear phagocytes, neutrophils and eosinophils during anaphylaxis. Int Arch Allergy Appl Immunol 1982; 67:219-26.

Edited by Vladimir PARFENOV 